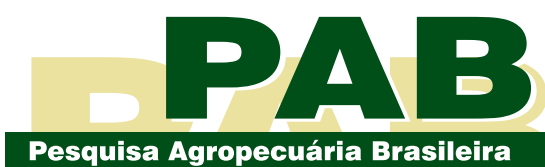

ISSN 1678-3921

Journal homepage: www.embrapa.br/pab

For manuscript submission and journal contents, access: www.scielo.br/pab

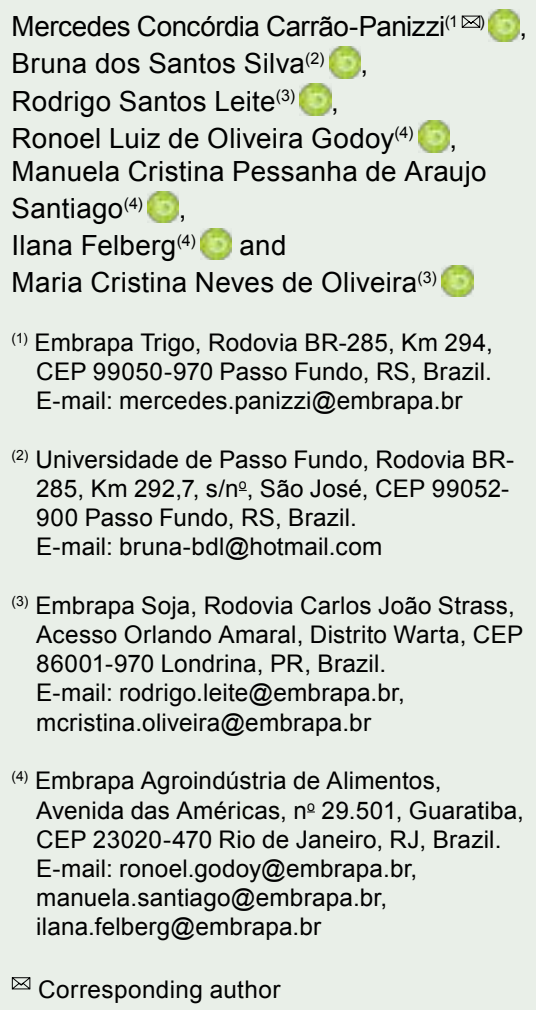

\section{Isoflavone, anthocyanin, and fatty acid contents of vegetable-type soybean grains at different maturity stages}

\begin{abstract}
The objective of this work was to determine the oil, protein, fatty acid, isoflavone, and anthocyanin contents in soybean grains of different breeding lines and maturity stages. Evaluations were performed for the chemical profiles of black- (BRM09-50995) and of yellow-seed-coat (BRM1151428 and BRM08-50643) breeding lines, harvested at the R6 (immature seeds), R7 (physiological maturity), and R8 (full maturity) maturity stages. Oil and protein contents increased from the R6 to the R8 stage, and BRM1151428 showed the highest protein content. Palmitic, stearic, and linolenic fatty acids were higher at R6, and linoleic and oleic acids were higher at R7 and R8, respectively. At the R8 growth stage, BRM11-51428 and BRM 09-50995 showed the highest contents of oleic and linoleic acids, respectively, and the lowest content of linolenic acid. The amounts of isoflavone glucosides and aglucones were higher at R8, while malonyl forms were higher at R7. Total aglucones increased about three times from R6 to R8. BRM09-50995 showed the highest content of total isoflavones and anthocyanins, mainly at the R8 stage, which makes this lineage an option to process functional soybean food.

Index terms: Glycine max, aglucone, breeding line, glucoside, oil, protein.

\section{Teores de isoflavonas, antocianinas e ácidos graxos, em grãos de soja tipo vegetal, em diferentes estádios de maturação}

Resumo - O objetivo deste trabalho foi determinar os teores de óleo, proteína, ácidos graxos, isoflavonas e antocianinas, em grãos de soja de diferentes linhagens e estádios de maturação. Foram feitas avaliações quantos aos perfis químicos das linhagens com tegumento preto (BRM09-50995) e amarelo (BRM11-51428 e BRM08-50643), colhidas nos estágios de maturidade R6 (sementes imaturas), R7 (maturidade fisiológica) e R8 (maturação completa). Os teores de óleo e proteína aumentaram do estágio R6 para o R8, e BRM1151428 apresentou o maior teor de proteína. Os teores de ácidos graxos palmítico, esteárico e linolênico foram maiores em R6, e os teores de ácidos linoleico e oleico foram maiores em R7 e R8, respectivamente. No estágio de crescimento R8, BRM11-51428 e BRM09-50995 apresentaram os maiores teores de ácido oleico e linoleico, respectivamente, e o menor teor de ácido linolênico. Os teores de isoflavonas glicosídeos e agliconas foram maiores em R8, enquanto as formas de malonil foram maiores em R7. Agliconas totais aumentaram cerca de três vezes de R6 para R8. BRM09-50995 apresentou o maior teor de isoflavonas totais e antocianinas, principalmente no estágio R8, o que torna esta linhagem uma opção para processar alimentos funcionais de soja.

Termos para indexação: Glycine max, agliconas, linhagem genética, glicosídeos, óleo, proteína. 


\section{Introduction}

Soybean is processed in a variety of food products, by using mature, or fresh grains. Grains harvested at different developmental stages of maturity (R6, R7, and R8) can be used for different type of products. The color, size, and chemical compounds (composition and concentration) of soybean grains change according to the plant maturity stages (Lee et al., 2013). Depending on the soybean genotype, grain color change from green (immature grain) to yellow, black, and brown (matured grain). Changes on the chemical composition also affect nutrition quality and health benefits of soybean for humans (Cheng et al., 2011). Therefore, evaluations of the chemical characteristics of soybean grains from R6 through R8 developmental stages could allow of indication of raw materials for different type of special food products.

Fehr et al. (1971) classified the development growth stages of soybean grains as follows: R6, end of seed development with green beans completely filled; R7, seed physiological maturity with $60 \%$ moisture; and $\mathrm{R} 8$, full seed maturity with $13 \%$ moisture. When grains are completely filled, but immature (R6), soybean has been traditionally consumed as vegetable, also known as edamame (Carrão-Panizzi et al., 2018b; Czaikoski et al., 2018). Large grain size and mild flavor are the main quality criteria for vegetable-type soybean, whose grains are different of the so-called commodities cultivars. A profile of nine anthocyanins can be found in black soybean grains, which are affected by genetic and environmental conditions, but cyanidin-3-O- $\beta-D-$ glycoside anthocyanin form is the major compound (Koh et al., 2014).

Isoflavones are also relevant compounds in soybean because of their biological impact on human health (Ko, 2014) and on soybean flavor (Ma et al., 2015). The isoflavone compounds found in soybean grains are genistin, daidzin, and glycitin, with their respectively chemical forms: $\beta$-glucosides (25\%), acetyl- $\beta$ glucosides (5\%), malonyl- $\beta$-glucosides (70 to $80 \%$ ), and aglucones (less than 2\%) (Villares et al., 2011). Comparing with other isoflavone forms, aglucones are faster absorbed and metabolized by the human organism (Yerramsetty et al., 2014).

Breeding soybean with special qualities for human consumption would allow of the availability of soybean cultivars for special uses, promoting innovation on food processing and on soybean production systems, which can include small-scale agribusiness. High-value-add soybean products for niche markets such as sprouts, edamame, and black seed coat, among others, are the characteristics of the special soybean genotypes. Therefore, the objective of this work was to evaluate the oil, protein, fatty acid, isoflavone and anthocyanin contents of soybean grains of different breeding lines and maturity stages.

\section{Materials and Methods}

The breeding lines BRM09-50995, BRM11-51428, and BRM08-50643 were sowed in a greenhouse in December 14, 2012, at Embrapa Trigo, in Passo Fundo, Rio Grande do Sul state, Brazil (28 $8^{\circ} 15^{\prime} 46^{\prime \prime S}$, $52^{\circ} 24^{\prime} 24^{\prime \prime} \mathrm{W}, 687 \mathrm{~m}$ altitude). Plants from 20 pots were harvested at each growth stage (R6, R7, and R8), from three replicates allocated in a randomized complete block design. Chemical analysis (oil, protein, fatty acids, and isoflavones) were performed at Embrapa Soja (Londrina, PR, Brazil). Fresh beans at R6 and R7 stages were lyophilized using the lyophilizer Liobrás (LIOTOP L101, Liobrás, São Carlos, SP, Brazil). After lyophilization grains were milled using a coffee grinder Cadence MDR301 (Cadence, Balneário Piçarras, SC, Brazil), and stored at $4{ }^{\circ} \mathrm{C}$ for further analysis. For anthocyanin determination, ground samples were analyzed at Embrapa Agroindústria de Alimentos, in Rio de Janeiro, RJ, Brazil.

Seed size was determined on a wet basis, in a Shimadzu BL320H scale (Shimadzu, Kyoto, Japan) by weighting samples of 100 seed, in three replicates. Oil and protein were analyzed on a dry basis, using near-infrared reflectance spectroscopy (NIR) FT-NIR Antaris II (Thermo Fisher Scientific, Waltham, MA, USA).

Fatty acid quantification was performed using gas chromatography (GC) according to the methodology of Abidi et al. (1999) and Rayford et al. (1994). From milled samples, $200 \mathrm{mg}$ were placed in $50 \mathrm{~mL}$ screw-cap plastic tubes. In each tube $5.0 \mathrm{~mL}$ sodium methoxide $\left(\mathrm{NaCH}_{3} \mathrm{OH}\right)$ at $1 \%$ were added, prepared from the dilution of a sodium methoxide solution at $25 \%$ [1:25 dilution with methanol (grade HPLC/UV]. The tubes were homogenized in a vortex tubes stirrer at 15 min intervals, for 1 hour of extraction, until complete esterification. After one hour, $1.0 \mathrm{~mL}$ aqueous glacial acetic acid at $10 \%$ and $10 \mathrm{~mL}$ of heptane grade HPLC/ 
UV were added, and homogenized in the vortex tubes stirrer. After $10 \mathrm{~min}, 2.0 \mathrm{~mL}$ of the upper heptane layer containing the fatty acids were transferred to GC vials for injection.

The analysis was performed in a gas chromatograph Trace GC Ultra (Thermo Fisher Scientific, Waltham, MA, USA), equipped with SP 2340, a capillary silica column (30 m length, $0.32 \mathrm{~mm}$ internal diameter), having as stationary phase a $0.25 \mathrm{~mm}$ thick polymer biscyanopropyl siloxane (Supelco Inc., Bellefonte, PA, USA). For the analysis, $2.0 \mathrm{uL}$ of the extract was injected at $250^{\circ} \mathrm{C}$. The analysis was accomplished in an isothermal column temperature of $170^{\circ} \mathrm{C}$ from 0 to $10 \mathrm{~min}$, followed by a "ramp" to $220^{\circ} \mathrm{C}$. The detector used was the flame-ionization (FID) at $300^{\circ} \mathrm{C}$ temperature. Gases used to carry out the samples for analysis were 5.0 SID ultrapure nitrogen $(40 \mathrm{~mL}$ $\left.\mathrm{min}^{-1}\right)$, 5.0 SID ultrapure hydrogen $\left(40 \mathrm{~mL} \mathrm{~min}^{-1}\right)$, and ultra-pure synthetic air $\left(450 \mathrm{~mL} \mathrm{~min}^{-1}\right)$. Quantitation was performed by an external standard method, using a prior calibration with a standard mix of fatty acid methyl esters - FAMe (Supelco, Bellefonte, PA, USA). The results were expressed in percentage of dry basis.

The isoflavone quantitative analysis was carried out by using high-performance liquid chromatography according to Berhow (2002). The isoflavones were extracted according to Carrão-Panizzi et al. (2002). For separation and quantifying of the isoflavones, the analyses were performed in a UPLC chromatographer Acquity (Waters, Milford, MA, USA) equipped with PDA detector. Isoflavones were eluted in a reverse phase column Acquity UPLC BEH C18 (Waters, Milford, MA,USA), in a gradient system compounded by methanol and water. Each one of the 12 isoflavone isomers were identified and quantified by comparing the retention time and absorbance spectra of their specific standard curves. Isoflavone concentration is expressed in mg $100 \mathrm{~g}^{-1}$ soy sample on a dry weight basis.

Anthocyanins analyses were performed according to Santiago et al. (2010), by using an HPLC chromatographic system Waters model Alliance 2695 (Waters, Milford, MA, USA) equipped with a Waters 2996 photodiode array detector. Anthocyanins were extracted according to Wang et al. (2014): $1 \mathrm{~g}$ of sample was extracted with methanol solution at $60 \%$, acidified with chloridric acid, in water bath at $50{ }^{\circ} \mathrm{C}$ for 1 hour, and agitated in vortex every $5 \mathrm{~min}$.
Anthocyanins were separated on a Thermo Scientific $\mathrm{C}_{18}$ BDS $(100 \mathrm{~mm} \times 4.6 \mathrm{~mm} ; 2.4 \mu \mathrm{m})$ column, using a gradient of acetonitrile, and 5\% aqueous formic acid as mobile phase at $1 \mathrm{~mL} \mathrm{~min}^{-1}$. Column temperature was set at $30^{\circ} \mathrm{C}$. Chromatograms were processed at $520 \mathrm{~nm}$ using Empower software (Waters, Milford, MA, USA). Anthocyanins were quantified by external standardization.

The statistical program Sanest (Zonta et al., 1982) was used to analyze all chemical data (analysis of variance and Tukey's test at 5\% probability). Chemical analyses were performed in four replicates.

\section{Results and Discussion}

The breeding lines at R6 maturity stage of development showed large grain size (Table 1). Lines BRM09-50995 and BRM11-51428 showed the largest grains at R7 maturity stage. BRM08-50643 showed the smallest grains at all maturity stages. Large seed size and more seed per pod, along with mild flavor and soft texture are the attributes for edamame, which is the traditional Japanese soybean food that consists of fresh green (immature) pods boiled in salt water (CarrãoPanizzi et al., 2018b). Since R6 stage is the proper time for edamame harvest, all lines are suitable for this use. BRM11-51428 showed the largest seed size in all growth stages.

All genotypes showed similar amounts of oil at all growth stages, except for the line BRM11-51428, that showed the lowest-oil content at R6 (Table 2). Protein content increased from R6 to R8 stages of seed development (Table 2). BRM11-51428 showed the highest-protein content at R7 and R8. A similar pattern was observed by Saldivar et al. (2011), which reported that oil was accumulated during the early stages, while

Table 1. Weight (g) of 100 grains of soybean breeding lines harvested at maturity stages R6, R7, and R8. (1)

\begin{tabular}{lccc}
\hline Breeding line & \multicolumn{3}{c}{ Seed maturity stage } \\
\cline { 2 - 4 } & R6 & R7 & R8 \\
\hline BRM09-50995 & $41.50 \pm 1.08 \mathrm{bB}$ & $47.67 \pm 1.31 \mathrm{bA}$ & $29.50 \pm 0.29 \mathrm{bC}$ \\
BRM11-51428 & $46.67 \pm 1.84 \mathrm{aB}$ & $63.67 \pm 0.85 \mathrm{aA}$ & $33.30 \pm 1.87 \mathrm{aC}$ \\
BRM08-50643 & $30.17 \pm 1.08 \mathrm{cA}$ & $28.00 \pm 0.85 \mathrm{cA}$ & $20.33 \pm 0.62 \mathrm{cB}$ \\
\hline
\end{tabular}

(1)Means followed by equal letters, uppercase in the lines and lowercase in the columns, do not differ by Tukey's test, at 5\% probability. R6, full green seed; R7, physiological maturity (60\% moisture); and R8, full maturity ( $13 \%$ moisture). 
protein content gradually increased. In general, all breeding lines showed protein concentration within the ranges found for soybean grains - 341 to $568 \mathrm{~g} \mathrm{~kg}^{-1}$ of total seed weight -, with a mean of $421 \mathrm{~g} \mathrm{~kg}^{-1}$ (Bellaloui et al., 2010). The presence of protein in soybean seed at maturity stage R6 makes the edamame a nutritive vegetable, mainly in comparison with other ordinary vegetables. As it is known, protein is the most valuable soybean compound for food applications (either human or animal feeding), determining the quality and price of the products.

In the present study, although the fatty acid contents vary differently among breeding lines and maturity stages, the fatty acid values are within the average range for soybean (Table 3). Sarkar et al. (2015) observed in whole seed the following average fatty acid profile: 11.2\% palmitic (C16:0), 3.6\% stearic (C18:0), 23.7\% oleic (C18:1), $52.4 \%$ linoleic (C18:2), and 5.7\% linolenic (C18:3) acids. In general, at all maturity stages, the line BRM08-50643 showed the highest concentration of linolenic and linoleic acids (except at R8), also showing the lowest content of oleic acid (Table 3), which confirms the inverted correlation between oleic and linoleic acids, as already reported by Bellaloui et al. (2010). Genetic breeding goals to increase oleic acid, and to reduce linoleic and linolenic acids, are important because they will contribute to improve oil stability, preventing oxidation and production of trans-fatty acids (Sarkar et al., 2015). Considering the growth stages, no major patterns were found among the genotypes, which

Table 2. Percentage (\%) of oil and protein in grains of soybean breeding lines harvested at maturity stages R6, R7, and R8. ${ }^{(1)}$

\begin{tabular}{lccc}
\hline Breeding line & \multicolumn{3}{c}{ Seed maturity stage } \\
\cline { 2 - 4 } & R6 Oil (\%) \\
\hline & \multicolumn{3}{c}{ R8 } \\
BRM08-50643 & $24.27 \pm 0.29 \mathrm{Aa}$ & $23.23 \pm 0.63) \mathrm{Aa}$ & $25.00 \pm 0.48 \mathrm{Aa}$ \\
BRM09-50995 & $23.66 \pm 0.66 \mathrm{Aa}$ & $24.15 \pm 0.51) \mathrm{Aa}$ & $24.27 \pm 0.48 \mathrm{Aa}$ \\
BRM11-51428 & $20.42 \pm 0.71 \mathrm{Bb}$ & $23.44 \pm 0.781 \mathrm{Aa}$ & $24.43 \pm 0.51 \mathrm{Aa}$ \\
\hline Mean & $22.78 \mathrm{~B}$ & $23.60 \mathrm{AB}$ \\
\hline \multicolumn{4}{c}{ Protein (\%) } \\
BRM08-50643 & $34.73 \pm 0.06 \mathrm{Bb}$ & $38.39 \pm 0.06 \mathrm{Ac}$ & $38.61 \pm 0.12 \mathrm{Ac}$ \\
BRM09-50995 & $37.49 \pm 0.08 \mathrm{Ca}$ & $39.60 \pm 0.08 \mathrm{Bb}$ & $41.10 \pm 0.11 \mathrm{Ab}$ \\
BRM11-51428 & $37.44 \pm 0.10 \mathrm{Ca}$ & $42.70 \pm 0.04 \mathrm{Ba}$ & $44.26 \pm 0.13 \mathrm{Aa}$ \\
\hline Mean & $36.56 \mathrm{C}$ & $40.23 \mathrm{~B}$ \\
\hline
\end{tabular}

corroborates the findings of Lee et al. (2013), who reported that the responses for content of fatty acids are not consistent as a group for each seed maturity stages (R6, R7, and R8).

There were differences among the breeding lines and growth stages for isoflavone contents (Table 4). As observed by Santana et al. (2012), total accumulation of $\beta$-glucosides and aglucones, for all lines, increased at 20 and $29 \%$, respectively, from R6 to R8 (Table 4). Berger et al. (2008) reported a continuous accumulation of total isoflavones up to maturity for soybean growing at a greenhouse and in the field. A different trend, however, was observed for malonyl- $\beta$-glucosides that are the major isoflavone form in soybean seed. All lines showed the highest concentration at R7, which decreased at R8 maturity stage (Tables 4 and 5). Carreras

Table 3. Percentage (\%) of fatty acids (palmitic, stearic, oleic, linoleic and linolenic), in grains of soybean breeding lines harvested at maturity stages R6, R7, and R8. (1)

\begin{tabular}{|c|c|c|c|}
\hline \multirow[t]{2}{*}{ Breeding line } & \multicolumn{3}{|c|}{ Seed maturity stage } \\
\hline & R6 & R7 & $\mathrm{R} 8$ \\
\hline & \multicolumn{3}{|c|}{ Palmitic (C16:0) $(11 \%)^{(2)}$} \\
\hline BRM08-50643 & $11.49 \pm 0.06 \mathrm{Bab}$ & $11.58 \pm 0.06 \mathrm{Ba}$ & $12.07 \pm 0.07 \mathrm{Aa}$ \\
\hline BRM09-50995 & $11.22 \pm 0.14 \mathrm{Ab}$ & $11.07 \pm 0.04 \mathrm{Ab}$ & $11.03 \pm 0.06 \mathrm{Ab}$ \\
\hline BRM11-51428 & $11.57 \pm 0.06 \mathrm{Aa}$ & $11.12 \pm 0.11 \mathrm{Bb}$ & $10.99 \pm 0.03 \mathrm{Bb}$ \\
\hline \multirow[t]{2}{*}{ Mean } & $11.43 \mathrm{~A}$ & $11.26 \mathrm{~B}$ & $11.36 \mathrm{AB}$ \\
\hline & \multicolumn{3}{|c|}{ Stearic $(\mathrm{C} 18: 0)(4 \%)^{(2)}$} \\
\hline BRM08-50643 & $4.10 \pm 0.001 \mathrm{Ba}$ & $3.89 \pm 0.005 \mathrm{Ca}$ & $4.30 \pm 0.09 \mathrm{Aa}$ \\
\hline BRM09-50995 & $3.51 \pm 0.014 \mathrm{Ab}$ & $3.36 \pm 0.001 \mathrm{Bb}$ & $3.35 \pm 0.01 \mathrm{Bb}$ \\
\hline BRM11-51428 & $3.24 \pm 0.003 \mathrm{Ac}$ & $3.10 \pm 0.007 \mathrm{Bc}$ & $2.92 \pm 0.007 \mathrm{Cc}$ \\
\hline \multirow[t]{2}{*}{ Mean } & $3.62 \mathrm{~A}$ & $3.45 \mathrm{C}$ & $3.52 \mathrm{~B}$ \\
\hline & \multicolumn{3}{|c|}{ Oleic $(\mathrm{C} 18: 1)(18-24 \%)^{(2)}$} \\
\hline BRM08-50643 & $18.55 \pm 0.01 \mathrm{Bc}$ & $16.50 \pm 0.007 \mathrm{Cc}$ & $19.11 \pm 0.03 \mathrm{Ac}$ \\
\hline BRM09-50995 & $21.46 \pm 0.03 \mathrm{Ab}$ & $21.21 \pm 0.01 \mathrm{Bb}$ & $21.25 \pm 0.02 \mathrm{Bb}$ \\
\hline BRM11-51428 & $24.39 \pm 0.05 \mathrm{Aa}$ & $23.25 \pm 0.03 \mathrm{Ba}$ & $24.46 \pm 0.01 \mathrm{Aa}$ \\
\hline \multirow[t]{2}{*}{ Mean } & $21.47 \mathrm{~B}$ & $20.32 \mathrm{C}$ & $21.61 \mathrm{~A}$ \\
\hline & \multicolumn{3}{|c|}{ Linoleic $(\mathrm{C} 18: 2)(54 \%)^{(3)}$} \\
\hline BRM08-50643 & $54.89 \pm 0.02 \mathrm{Ba}$ & $56.36 \pm 0.04 \mathrm{Aa}$ & $53.73 \pm 0.03 \mathrm{Cb}$ \\
\hline BRM09-50995 & $53.50 \pm 0.08 \mathrm{Bb}$ & $55.09 \pm 0.04 \mathrm{Ab}$ & $55.26 \pm 0.02 \mathrm{Aa}$ \\
\hline BRM11-51428 & $50.65 \pm 0.06 \mathrm{Cc}$ & $52.73 \pm 0.08 \mathrm{Ac}$ & $52.21 \pm 0.02 \mathrm{Bc}$ \\
\hline \multirow[t]{2}{*}{ Mean } & $53.01 \mathrm{C}$ & $54.73 \mathrm{~A}$ & 53.73B \\
\hline & \multicolumn{3}{|c|}{ Linolenic $(\mathrm{C} 18: 3)(6-8 \%)^{(2)}$} \\
\hline BRM08-50643 & $10.65 \pm 0.004 \mathrm{Ba}$ & $11.25 \pm 0.02 \mathrm{Aa}$ & $10.34 \pm 0.006 \mathrm{Ca}$ \\
\hline BRM09-50995 & $9.93 \pm 0.02 \mathrm{Ac}$ & $8.90 \pm 0.012 \mathrm{Bc}$ & $8.76 \pm 0.006 \mathrm{Cc}$ \\
\hline BRM11-51428 & $10.06 \pm 0.01 \mathrm{Ab}$ & $9.73 \pm 0.021 \mathrm{Bb}$ & $9.42 \pm 0.006 \mathrm{Cb}$ \\
\hline Mean & $10.21 \mathrm{~A}$ & $9.96 \mathrm{~B}$ & $9.51 \mathrm{C}$ \\
\hline \multicolumn{4}{|c|}{$\begin{array}{l}{ }^{(1)} \text { Means ( } 4 \text { replicates) followed by equal letters, uppercase in the lines and } \\
\text { lowercase in the columns, do not differ by Tukey's test, at } 5 \% \text { probability. } \\
\text { (2) Average value in soybean (Bellaloui et al., 2010; Sarkar et al., 2015). } \\
\text { R6, full green seed; R7, physiological maturity ( } 60 \% \text { moisture); R8, full } \\
\text { maturity ( } 13 \% \text { moisture). }\end{array}$} \\
\hline
\end{tabular}


\& Dardanelli (2016) observed that total isoflavone contents decreased linearly with rising temperatures and increasing water deficit. Malonyl isoflavones are unstable and heat label compounds that are affected by high temperatures (environment and processing) (Kudou et al., 1991). Probably, at soybean maturation (R8), greenhouse temperatures that were not measured were higher causing the decrease of malonyl forms. Additional studies should be carried out to elucidate this difference on malonyl compounds. BRM11-51428 showed the lowest content of total isoflavones at all maturity stages (Table 4). BRM09-50995 showed the highest content of glucosides and aglucones, showing also a considerable amount of total isoflavone (586.25 $\mathrm{mg} 100 \mathrm{~g}^{-1}$ ) at full maturity (R8) (Table 4).

Comparing mature (R8) with immature (R6) seed, the amount of malonyl daidzin and malonyl genistin were smaller in the later (Table 5). Therefore, the flavor of vegetable soybean (edamame) could be favored by less bitterness and astringency of these compounds as reported by Aldin et al. (2006).

Glycitin forms were present in small amounts and with a great variability in all periods of grain maturation (Tables 5). Total aglucone isoflavones, the readily available compounds, showed a significantly increase from R6 to R8 (Table 5).
Table 4. Total content (mg $\left.100 \mathrm{~g}^{-1}\right)$ of isoflavones $\beta$-glucosides, malonyls, and aglucones - in grains of soybean breeding lines harvested at maturity stages R6, R7 and $\mathrm{R} 8^{(1)}$.

\begin{tabular}{lccc}
\hline Breeding line & \multicolumn{3}{c}{ Seed maturity stage } \\
\cline { 2 - 4 } & R6 & R7 & R8 8 \\
\hline & \multicolumn{3}{c}{-glucosides } \\
BRM08-50643 & $25.65 \pm 0.43 \mathrm{Ca}$ & $41.64 \pm 0.16 \mathrm{Ba}$ & $104.29 \pm 4.32 \mathrm{Ab}$ \\
BRM09-50995 & $27.14 \pm 2.28 \mathrm{Ca}$ & $45.39 \pm 2.76 \mathrm{Ba}$ & $153.33 \pm 0.83 \mathrm{Aa}$ \\
BRM11-51428 & $14.89 \pm 1.04 \mathrm{Cb}$ & $28.67 \pm 0.46 \mathrm{Bb}$ & $81.32 \pm 4.017 \mathrm{Ac}$ \\
\hline Mean & $22.56 \mathrm{C}$ & $38.56 \mathrm{~B}$ & $112.98 \mathrm{~A}$ \\
\hline \multicolumn{4}{c}{ Total malonyl glucosides } \\
BRM08-50643 & $219.89 \pm 1.86 \mathrm{Ca}$ & $514.35 \pm 1.58 \mathrm{Aa}$ & $352.81 \pm 15.80 \mathrm{Bb}$ \\
BRM09-50995 & $205.06 \pm 23.55 \mathrm{Ca}$ & $509.40 \pm 21.35 \mathrm{Aa}$ & $413.61 \pm 25.11 \mathrm{Ba}$ \\
BRM11-51428 & $170.67 \pm 7.67 \mathrm{Cb}$ & $456.77 \pm 5.94 \mathrm{Ab}$ & $280.71 \pm 3.06 \mathrm{Bc}$ \\
\hline Mean & $194.44 \mathrm{C}$ & $501.84 \mathrm{~A}$ \\
\hline & \multicolumn{4}{c}{ Total aglucones } \\
BRM08-50643 & $3.45 \pm 0.093 \mathrm{Cb}$ & $7.29 \pm 0.58 \mathrm{Bb}$ & $14.53 \pm 0.45 \mathrm{Ab}$ \\
BRM09-50995 & $6.28 \pm 0.56 \mathrm{Ca}$ & $10.53 \pm 0.40 \mathrm{Ba}$ & $19.31 \pm 0.78 \mathrm{Aa}$ \\
BRM11-51428 & $1.48 \pm 0.02 \mathrm{Bc}$ & $2.24 \pm 0.06 \mathrm{Bc}$ & $5.06 \pm 0.71 \mathrm{Ac}$ \\
\hline Mean & $3.74 \mathrm{C}$ & $6.68 \mathrm{~B}$ \\
\hline \\
& \multicolumn{4}{c}{ Total isoflavones } \\
BRM08-50643 & $249.00 \pm 3.62 \mathrm{Ca}$ & $563.28 \pm 1.74 \mathrm{Aa}$ & $471.65 \pm 1.90 \mathrm{Bb}$ \\
BRM09-50995 & $238.48 \pm 12.18 \mathrm{Ca}$ & $565.32 \pm 1.8 \mathrm{Ba}$ & $586.25 \pm 1.81 \mathrm{Aa}$ \\
BRM11-51428 & $187.04 \pm 8.72 \mathrm{Cb}$ & $487.68 \pm 6.38 \mathrm{Ab}$ & $367.09 \pm 7.25 \mathrm{Bc}$ \\
\hline Mean & $224.84 \mathrm{C}$ & $525.05 \mathrm{~A}$ & $475.00 \mathrm{~B}$ \\
\hline
\end{tabular}

${ }^{(1)}$ Means followed by equal letters, uppercase in the lines and lowercase in the columns, do not differ by Tukey's test, at 5\% probability. R6, full green seed; R7, physiological maturity ( $60 \%$ moisture); R8, full maturity ( $13 \%$ moisture).

Table 5. Content of isoflavones $\left(\mathrm{mg} 100 \mathrm{~g}^{-1}\right)$ in grains of soybean (Glycine max) breeding lines harvested at maturity stages ${ }^{(1)}$ $\mathrm{R} 6, \mathrm{R} 7$, and $\mathrm{R} 8^{(2)}$.

\begin{tabular}{|c|c|c|c|c|c|c|c|c|c|}
\hline \multirow[t]{2}{*}{ Breeding line } & \multicolumn{3}{|c|}{ Isoflavone $\beta$-glucosides } & \multicolumn{3}{|c|}{ Malonyl glucosides } & \multicolumn{3}{|c|}{ Aglucones } \\
\hline & R6 & R7 & $\mathrm{R} 8$ & R6 & R7 & $\mathrm{R} 8$ & R6 & R7 & $\mathrm{R} 8$ \\
\hline & \multicolumn{3}{|c|}{ Daidzin } & \multicolumn{3}{|c|}{ Malonyl daidzin } & \multicolumn{3}{|c|}{ Daidzein } \\
\hline BRM08-50643 & $12.51 \pm 0.17 \mathrm{Ca}$ & $20.70 \pm 0.06 \mathrm{Ba}$ & $54.13 \pm 0.41 \mathrm{Ab}$ & $84.02 \pm 2.59 \mathrm{Ca}$ & $178.61 \pm 2.08 \mathrm{Aa}$ & $125.81 \pm 5.31 \mathrm{Bb}$ & $2.14 \pm 0.09 \mathrm{Ba}$ & $2.31 \pm 0.01 \mathrm{Ba}$ & $4.43 \pm 0.19 \mathrm{Ab}$ \\
\hline BRM09-50995 & $12.02 \pm 0.90 \mathrm{Ca}$ & $21.61 \pm 1.07 \mathrm{Ba}$ & $79.43 \pm 0.50 \mathrm{Aa}$ & $80.67 \pm 2.59 \mathrm{Ca}$ & $173.05 \pm 2.79 \mathrm{Ab}$ & $147.36 \pm 2.66 \mathrm{Ba}$ & $0.93 \pm 0.15 \mathrm{Cb}$ & $1.79 \pm 0.03 \mathrm{Bb}$ & $6.31 \pm 0.03 \mathrm{Aa}$ \\
\hline BRM11-51428 & $6.91 \pm 0.46 \mathrm{Cb}$ & $13.79 \pm 0.22 \mathrm{Bb}$ & $37.52 \pm 0.41 \mathrm{Ac}$ & $59.82 \pm 3.88 \mathrm{Cb}$ & $142.58 \pm 1.41 \mathrm{Ac}$ & $81.79 \pm 2.78 \mathrm{Bc}$ & $1.03 \pm 0.01 \mathrm{Cb}$ & $1.59 \pm 4.39 \mathrm{Bb}$ & $2.70 \pm 0.17 \mathrm{Ac}$ \\
\hline \multirow[t]{2}{*}{ Mean } & $10.48 \mathrm{C}$ & $18.70 \mathrm{~B}$ & $60.26 \mathrm{~A}$ & $74.84 \mathrm{C}$ & $164.75 \mathrm{~A}$ & $118.32 \mathrm{~B}$ & $1.37 \mathrm{C}$ & $1.89 \mathrm{~B}$ & $4.48 \mathrm{~A}$ \\
\hline & \multicolumn{3}{|c|}{ Glycitin } & \multicolumn{3}{|c|}{ Malonyl glycitin } & \multicolumn{3}{|c|}{ Glycitein } \\
\hline BRM08-50643 & $6.28 \pm 0.31 \mathrm{Bb}$ & $6.25 \pm 0.19 \mathrm{Ba}$ & $7.68 \pm 0.31 \mathrm{Ab}$ & $23.52 \pm 0.74 \mathrm{Ab}$ & $25.36 \pm 0.97 \mathrm{Aa}$ & $17.62 \pm 0.72 \mathrm{Bb}$ & $0.0 \mathrm{C}$ & $3.85 \pm 0.33 \mathrm{~B}$ & $6.32 \pm 0.27 \mathrm{~A}$ \\
\hline BRM09-50995 & $11.44 \pm 0.21 \mathrm{Ba}$ & $7.12 \pm 0.15 \mathrm{Cb}$ & $20.35 \pm 0.25 \mathrm{Aa}$ & $51.54 \pm 3.03 \mathrm{Aa}$ & $34.05 \pm 2.86 \mathrm{Ba}$ & $40.57 \pm 2.86 \mathrm{Aa}$ & $4.48 \pm 0.38 \mathrm{C}$ & $7.58 \pm 0.35 \mathrm{~B}$ & $8.95 \pm 0.70 \mathrm{~A}$ \\
\hline BRM11-51428 & $4.92 \pm 0.51 \mathrm{Bc}$ & $3.48 \pm 0.09 \mathrm{Cc}$ & $6.37 \pm 0.69 \mathrm{Ac}$ & $25.65 \pm 1.84 \mathrm{Ab}$ & $21.67 \pm 0.24 \mathrm{Aa}$ & $15.40 \pm 1.21 \mathrm{Bb}$ & 0.0 & 0.0 & 0.0 \\
\hline Mean & $7.55 \mathrm{~B}$ & $5.62 \mathrm{C}$ & $11.47 \mathrm{~A}$ & $33.57 \mathrm{~A}$ & $27.03 \mathrm{~A}$ & $24.53 \mathrm{~B}$ & $1.49 \mathrm{C}$ & $3.81 \mathrm{~B}$ & $5.09 \mathrm{~A}$ \\
\hline
\end{tabular}

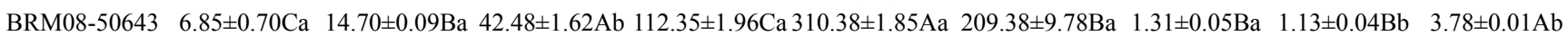
BRM09-50995 $3.68 \pm 0.16 \mathrm{Cb} \quad 16.66 \pm 0.40 \mathrm{Ba} \quad 53.55 \pm 1.50 \mathrm{Aa} \quad 72.85 \pm 1.85 \mathrm{Cb} \quad 302.30 \pm 5.74 \mathrm{Aa} \quad 225.68 \pm 7.36 \mathrm{Ba} \quad 0.87 \pm 0.04 \mathrm{Cb} \quad 1.16 \pm 0.025 \mathrm{Ba} \quad 4.05 \pm 0.03 \mathrm{Aa}$

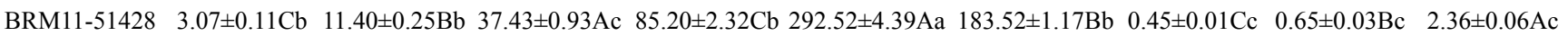

\begin{tabular}{|c|c|c|}
\hline Mean & $4.53 \mathrm{C}$ & $14.25 \mathrm{~B}$ \\
\hline
\end{tabular}

${ }^{(1)}$ R6, full green seed; R7, physiological maturity (60\% moisture); and R8, full maturity (13\% moisture). ${ }^{(2)}$ Means followed by equal letters, uppercase in the lines and lowercase in the columns, do not differ by Tukey's test, at $5 \%$ probability. 
Anthocyanins were expressed in similar amounts as observed in Korean black-soybean-seed varieties (Koh et al., 2014). They were present only in line BRM09-50995, which shows a black seed coat. Three anthocyanins were identified as: delphinidin3-glucoside (D3G), cyanidin-3-glucoside (C3G), and petunidin-3-glucoside (Pe3G); the cyanidin-3glucoside form occurred in at a higher concentration than the other compounds (Figure 1). Total content of anthocyanins were present as follows: at R7, $148.7 \mathrm{mg}$ $100 \mathrm{~g}^{-1}$; at R6, $26.5 \mathrm{mg} 100 \mathrm{~g}^{-1}$; and at R8, $37.7 \mathrm{mg} 100$ $\mathrm{g}^{-1}$ (Figure 1). It is noteworthy that higher amounts of total anthocyanins occurred at R7 maturity stage. Lee et al. (2013) observed the same trend, explaining that as anthocyanins are water-soluble and unstable compounds, their content was reduced at R8 because of seed dehydration during maturation. Therefore, depending on the stage, like $\mathrm{R} 8$ at harvest, seed may have lower moisture and less anthocyanins. At physiological maturity (R7), seed moisture is about

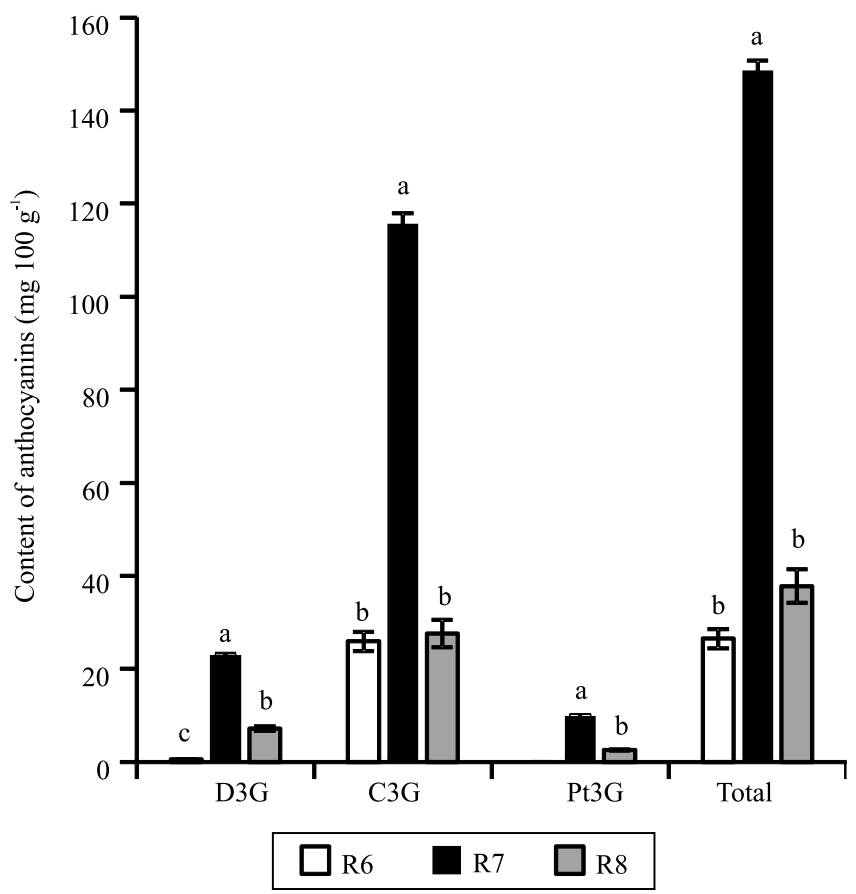

Figure 1. Content of delphinidin-3-O- $\beta$-D-glucoside (D3G), cyanidin-3-O- $\beta$-D-glucoside (C3G), petunidin-3-O$\beta$-D-glucoside (Pt3G), and total anthocyanins, in grains of the breeding line BRM09-50995 harvested at the folllowing maturity stages: R6, full green seed; R7, physiological maturity (60\% moisture); and R8, full maturity (13\% moisture). Means followed equal letters do not differ by Tukey's test, at 5\% probability.
$60 \%$, decreasing to around $13 \%$ at harvest. Variations of moisture from R7 to R8 could result in different concentrations of anthocyanins, as observed by CarrãoPanizzi et al. (2018a), who found a high concentration of total anthocyanins at R8 growth stages.

The identification of changes on chemical metabolites at different stages of seed maturation is important for decision to be taken on the best harvest time, as well as on processing of nutritious food products. Vegetable soybean suited for fresh uses, in general, is larger-seeded, and has a sweet flavor, soft texture, besides being more digestible than grains of commodities-type soybean.

Therefore, all lines in the present study showed good chemical attributes to be consumed as vegetable, since they are harvested at R6 growth stage. BRM09-50995, with black seed coat, larger grains at all seed maturity stages, measured by weighing (g) of 100 seed (R6, $41 \mathrm{~g}$ $\left.\mathrm{kg}^{-1} ; \mathrm{R} 7,48 \mathrm{~g} \mathrm{~kg}^{-1} ; \mathrm{R} 8,30 \mathrm{~g} \mathrm{~kg}^{-1}\right)$, and with high contents of isoflavones and anthocyanins, is a promising raw material for processing functional foods.

\section{Conclusions}

1. Protein, oleic fatty acid, $\beta$-glucoside and aglucone isoflavones are present at higher concentrations in matured soybean grains (R8 growth stage) than in immature soybean.

2. Anthocyanins are only present in black-seeded soybean, and both anthocyanins and malonyl isoflavones occur at high concentrations in grains at the R7 stage (physiological maturity).

3. The chemical composition of soybean breeding lines shows that they are suitable for human consumption at any grain growth stage of development (R6 to R8).

\section{Acknowledgments}

To Conselho Nacional de Desenvolvimento Científico e Tecnológico (CNPq), for partially supporting the grant 471593/2012-5; and to Antônio Ricardo Panizzi, for critically reading the manuscript.

\section{References}

ABIDI, S.L.; LIST, G.R.; RENNICK, K.A. Effect of genetic modification on the distribution of minor constituents in canola 
oil. Journal of the American Oil Chemists Society, v.76, p.463467, 1999. DOI: https://doi.org/10.1007/s11746-999-0025-3.

ALDIN, E.; REITMEIER, C.A.; MURPHY, P. Bitterness of soy extracts containing isoflavones and saponins. Journal of Food Science, v.71, p.S211-S215, 2006. DOI: https://doi.org/10.1111/j.1365-2621.2006.tb15643.x.

BELLALOUI, N.; BRUNS, A.H; GILLEN, A.M.; ABBAS, H.K.; ZABLOTOWICZ, R.M.; MENGISTU, A.; PARIS, R.L. Soybean seed protein, oil, fatty acids, and mineral composition as influenced by soybean-corn rotation. Agricultural Sciences, v.1, p.102-109, 2010. DOI: https://doi.org/10.4236/as.2010.13013.

BERGER, M.; RASOLOHERY, C.A.; CAZALIS, R.; DAYDÉ, J. Isoflavone accumulation kinetics in soybean seed cotyledons and hypocotyls: distinct pathways and genetic controls. Crop Science, v.48, p.700-708, 2008. DOI: https://doi.org/10.2135/ cropsci2007.08.0431.

BERHOW, M.A. Modern analytical techniques for flavonoid determination. In: BUSLIG, B.S.; MANTHEY, J.A. (Ed.). Flavonoids in cell function. New York: Klusher Academic, 2002. p.61-76. DOI: https://doi.org/10.1007/978-1-4757-5235-9_6.

CARRÃO-PANIZZI, M.C.; FAVONI, S.P.de G.; KIKUCHI, A. Extraction time for soybean isoflavone determination. Brazilian Archives of Biology and Technology, v.45, p.515-518, 2002. DOI: https://doi.org/10.1590/S1516-89132002000600015.

CARRÃO-PANIZZI, M.C.; MIRANDA, M.Z. de; FELBERG, I.; GODOY, R.L. de O.; SANTIAGO, M.C.P. de A. Avaliação de soja preta para consumo como edamame. Passo Fundo: Embrapa Trigo, 2018a. 20p. (Embrapa Trigo. Boletim de pesquisa e desenvolvimento, 89). Available at: <http:/ainfo. cnptia.embrapa.br/digital/bitstream/item/179670/1/ID443512018BPDO189.pdf>. Accessed on: Feb. 12019.

CARRÃO-PANIZZI, M.C.; OLIVEIRA, M.A. de; SANTOS, H.P. dos; MANDARINO, J.M. G.; OLIVEIRA, M.C.N. de. Características de vagens e grãos de cultivares de soja para utilização como edamame. Londrina: Embrapa Soja, 2018b. 24p. (Embrapa Soja. Boletim de pesquisa e desenvolvimento, 20).

CARRERA, C.S.; DARDANELLI, J.L. Changes in the relationship between temperature during the seed-filling period and soya bean seed isoflavones under water-deficit conditions. Journal of Agronomy and Crop Science, v.202, p.421-432, 2016. DOI: https://doi.org/10.1111/jac.12147.

CHENG, K-C.; LIN, J.-T.; LIU, W.H. Extracts from fermented black soybean milk exhibit antioxidant and cytotoxic activities. Food Technology and Biotechnology, v.49, p.111-117, 2011.

CZAIKOSKI, K.; LEITE, R.S.; MANDARINO, J.M.G.; CARRÃO-PANIZZI, M.C.; SILVA, J.B. da; IDA, E.I. Physicochemical characteristics of canned vegetable-type soybean processed with zinc at different pasteurization times. Pesquisa Agropecuária Brasileira, v.53, p.840-848, 2018. DOI: https://doi.org/10.1590/S0100-204X2018000700008.

FEHR, W.R.; CAVINESS, C.E.; BURMOOD, D.T.; PENNINGTON, J.S. Stage of development descriptions for soybeans, Glycyne max L. Merrill. Crop Science, v.11, p.929-931, 1971. DOI: https://doi.org/10.2135/ cropsci1971.0011183X001100060051x.

KO, K.-P. Isoflavones: chemistry, analysis, functions and effects on health and cancer. Asian Pacific Journal of Cancer Prevention, v.15, p.7001-7010, 2014. DOI: https://doi.org/10.7314/ APJCP.2014.15.17.7001.

KOH, K.; YOUN, J.E.; KIM, H.-S. Identification of anthocyanins in black soybean (Glycine max (L.) Merr.) varieties. Journal of Food Science and Technology, v.51, p.377-381, 2014. DOI: https://doi.org/10.1007/s13197-011-0493-y.

KUDOU, S.; FLEURY, Y.; WELTI, D.; MAGNOLATO, D.; UCHIDA, T.; KITAMURA, K.; OKUBO, K. Malonyl isoflavone glycosides in soybean seeds (Glycine max Merrill). Agricultural and Biological Chemistry, v.55, p.2227-2233, 1991. DOI: https://doi.org/10.1271/bbb1961.55.2227.

LEE, J.; HWANG, Y.-S.; CHANG, W.-S.; MOON, J.-K.; CHOUNG, M.-G. Seed maturity differentially mediates metabolic responses in black soybean. Food Chemistry, v.141, p.20522059, 2013. DOI: https://doi.org/10.1016/j.foodchem.2013.05.059.

MA, L.; LI, B.; HAN, F.; YAN, S.; WANG, L.; SUN, J. Evaluation of the chemical quality traits of soybean seeds, as related to sensory attributes of soymilk. Food Chemistry, v.173, p.694-701, 2015. DOI: https://doi.org/10.1016/j.foodchem.2014.10.096.

RAYFORD, W.E.; THOMAS, D.I.; ELAM, L.M.; WALKER, S.M. Analytical chemical support soybean uniform test analysis. Peoria: USDA, 1994. p.17-26.

SALDIVAR, X.; WANG, Y.-J.; CHEN, P.; HOU, A. Changes in chemical composition during soybean seed development. Food Chemistry, v.124, p.1369-1375, 2011. DOI: https://doi.org/10.1016/j.foodchem.2010.07.091.

SANTANA, A.C.; CARRÃO-PANIZZI, M.C.; MANDARINO, J.M. G.; LEITE, R.S.; SILVA, J.B. da; IDA, E.I. Effect of harvest at different times of day on the physical and chemical characteristics of vegetable-type soybean. Ciência e Tecnologia de Alimentos, v.32, p.351-356, 2012. DOI: https://doi.org/10.1590/ S0101-20612012005000044.

SANTIAGO, M.C.P. de A.; GOUVÊA, A.C.M.S.; GODOY, R.L. de O.; OIANO NETO, J.; PACHECO, S.; ROSA, J.S. da. Adaptação de um método por cromatografia líquida de alta eficiência para análise de antocianinas em suco de açaí (Euterpe oleraceae Mart.). Rio de Janeiro: Embrapa Agroindústria de Alimentos, 2010. (Embrapa Agroindústria de Alimentos. Comunicado técnico, 162).

SARKAR, A.; GOLAY, P.-A.; ACQUISTAPACE, S.; CRAFT, B.D. Increasing the oxidative stability of soybean oil through fortification with antioxidants. International Journal of Food Science and Technology, v.50, p.666-673, 2015. DOI: https://doi.org/10.1111/ijfs.12671.

VILLARES, A.; ROSTAGNO, M.A.; GARCÍA-LAFUENTE, A.; GUILLAMÓN, E.; ALFREDO MARTÍNEZ, J. Content and profile of isoflavones in soy-based foods as a function of the production process. Food Bioprocess Technology, v.4, p.27-38, 2011. DOI: https://doi.org/10.1007/s11947-009-0311-y. 
WANG, D.; MA, Y.; ZHANG, C.; ZHAO, X. Thermal characterization of the anthocyanins from black soybean (Glycine $\max$ L.) exposed to thermogravimetry. Food Science and Technology, v.55, p.645-649, 2014. DOI: https://doi.org/10.1016/j. lwt.2013.10.007.

YERRAMSETTY, V.; GALLAHER, D.D.; ISMAIL, B. Malonylglucoside conjugates of isoflavones are much less bioavailable compared with unconjugated $\beta$-glucosidic forms in rats. Journal of Nutrition, v.144, p.631-637, 2014. DOI: https://doi.org/10.3945/jn.114.190801.

ZONTA, E.P.; MACHADO, A.A.; SILVEIRA JR., P. Sistema de análise estatística. Pelotas: Universidade Federal de Pelotas, 1982. 63p. 